\title{
A komputertomográfia jelentősége az eventerált, óriás hasfali sérvek mǘtéteinek tervezésében
}

\author{
Martis Gábor dr. ${ }^{1}$ - Laczik Renáta dr. ${ }^{2}$ - Damjanovich László dr. ${ }^{1}$ \\ Debreceni Egyetem, Általános Orvostudományi Kar, Klinikai Központ, ${ }^{1}$ Sebészeti Intézet, \\ ${ }^{2}$ Belgyógyászati Intézet, Angiológiai Tanszék, Debrecen
}

\begin{abstract}
Bevezetés: Az eventerált, óriás hasfali sérvek megoldása jelentős kihívást jelent. A hasfali elemek részletes CT-vizsgálata jelenleg nem része a lehetséges mútéti megoldások megtervezésének. Célkituzés: Nyitotthas-kezelések vagy intraabdominalis sorozatmütétek után kialakuló hasfalisérv-fejlődés dinamikájának meghatározása, illetve a hasfali struktúrák változásának követése. Módszer: Az 1., a 3., a 6., a 12., a 18. és a 24. posztoperatív hónapban CT-vizsgálatokat végeztünk 2012. január l. és 2015. december 31. között 12 beteg esetében, akiknél a középvonal rekonstrukciója nem volt lehetséges a primer mütétsorozat befejezése után. Az adatok konszekutív, prospektív gyưjtését végeztük el. A vizsgálat során meghatároztuk a középvonali hasfalhiány növekedésének a dinamikáját, a középvonali hasfalhiány méretének, a kétoldali rectus abdominis izom morfológiájának változását. Eredmények: A középvonali hasfalhiány folyamatos, jellegzetes növekedést mutatott. A kétoldali rectusizom együttes szélessége feszülés nélkül képes lefedni a középvonali hasfalhiányt, de csak egy optimális időintervallumban. Következtetés: Az eventerált hasfali sérvek rekonstrukciója előtt végzett CT-vizsgálat meghatározó jelentőségú az optimális mútéti megoldás meghatározásában. Orv. Hetil., 2017, 158(7), 257-263.
\end{abstract}

Kulcsszavak: hasfali sérv, CT-vizsgálat, eventeratio, középvonali hasfalhiány, sajátszövet-rekonstrukció

\section{Significance of the computed tomography assisted morphometry in the surgical planning of eventrated abdominal wall hernias}

Introduction: The eventrated, giant abdominal wall hernias represent a considerable challenge in our practice. Presently, preoperative evaluation of the musculo-aponeurotic elements of the abdominal wall by CT imaging is not part of routine planning of surgery. Aim: Evaluation of the abdominal wall hernia progression in time. Moreover, follow up the changes of the abdominal wall structures following series of intraabdominal surgeries. Method: Abdominal CT imaging were performed on the 1st, 3rd, 6th, 12th, 18th, and 24th postoperative months after the primary series of surgeries in the cases of 12 patients, whose reconstructive surgeries were not possible. A prospective data collection was applied. Changing of the bilateral rectus muscle morphology, the evolution in time of the midline gap, and the progressive dynamism of the midline wall defects were determined. Results: A characteristic and progressive midline defect enlargement could be settled. Data analysis yielded that the combined width of the bilateral rectus muscles is sufficient to cover the midline abdominal wall defect, although there is an "optimal" timeframe for performing the intervention. Conclusion: CT evaluation of abdominal wall prior to reconstructive surgeries of loss of abdominal wall domain has a strong significance on determining and designing the adequate surgical procedure.

Keywords: abdominal wall hernia, computed tomography, eventration, midline defect, autologous reconstruction

Martis, G., Laczik, R., Damjanovich, L. [Significance of the computed tomography assisted morphometry in the surgical planning of eventrated abdominal wall hernias]. Orv. Hetil., 2017, 158(7), 257-263.

(Beérkezett: 2016. november 14.; elfogadva: 2016. december 16.) 


\section{Rövidítések}

ACS = anterior component separation; ADM = acellular dermal matrix; ASA = American Society of Anesthesiologists; $\mathrm{BMI}=$ body mass index CDCP $=$ Control of Disease Centers and Prevention; COPD = chronic obstructive pulmonary disease; CT = computed tomography; DE KK = Debreceni Egyetem, Klinikai Központ; DM = diabetes mellitus; KV = kilovolt; $\mathrm{L}=$ lumbalis $; \mathrm{mA}=$ milliamper $; \mathrm{MRI}=$ magnetic resonance imaging; NYHA = New York Heart Association; PCS = posterior component separation; $\mathrm{TAR}=$ transversus abdominis release $; \mathrm{Th}=$ thoracalis $; \mathrm{VAC}=$ vacuum-assisted closure

Az eventerált hasfali sérvek és a nagyméretû́ hasfalhiányok kizárólag mútéti beavatkozással kezelhetők, amelyek jelentős kihívást jelentenek a kezelőszemélyzet számára és magas kockázatú beavatkozás a betegre nézve [1-5]. A beavatkozások eredményességét a hasfal állapotának pontos felmérésével is lehetne javítani. Nem ismert azonban, hogy milyen a sérv növekedésének a dinamikája, milyen változások történnek a hasfal musculoaponeuroticus elemeiben, ami végső soron az eventeratióhoz vezet. A különböző okok miatt végzett nyitotthas-kezelések és a retroperitonealis és intraabdominalis sorozatmütétek után szinte törvényszerű a jelentős középvonali hasfalhiány és az eventerált hasfali sérvek kialakulása.

1. táblázat |A tanulmány beválogatási és kizárási kritériumai

\begin{tabular}{|c|c|c|c|}
\hline & \multicolumn{3}{|c|}{ Kritérium } \\
\hline & Beválasztási & & Kizárási \\
\hline 1 & $\begin{array}{l}\text { Aláírt beleegyező } \\
\text { nyilatkozat }\end{array}$ & 1 & CDCP IV hasfali környezet \\
\hline 2 & Kor $\geq 18$ év & 2 & NYHA IV. stádium \\
\hline 3 & $\begin{array}{l}\text { A középvonal zárása nem } \\
\text { kivitelezhető }\end{array}$ & 3 & ASA IV-V. stádium \\
\hline 4 & Hasüregi sorozatmútétek & 4 & Aktuális malignus betegség \\
\hline 5 & $\begin{array}{l}\text { Nyitotthas- vagy VAC- } \\
\text { kezelés }\end{array}$ & 5 & $\begin{array}{l}\text { Aktuális kemo- és/vagy } \\
\text { sugárkezelés }\end{array}$ \\
\hline 6 & $\begin{array}{l}\text { Teljes középvonali } \\
\text { hasfalhiány }\end{array}$ & 6 & Dekompenzált májmúködés \\
\hline 7 & $\begin{array}{l}\text { Nincs jele az eredeti } \\
\text { hasürregi betegségnek }\end{array}$ & 7 & Terápiarezisztens ascites \\
\hline 8 & $\begin{array}{l}\text { Nincs jele a } \\
\text { retroperitoneum } \\
\text { érintettségének }\end{array}$ & 8 & Akut pancreatitis \\
\hline 9 & $\begin{array}{l}\text { Nincs jele enterocutan } \\
\text { fistulának }\end{array}$ & 9 & $\begin{array}{l}\text { Krónikus pancreatitis akut } \\
\text { fellángolással }\end{array}$ \\
\hline \multirow[t]{6}{*}{10} & $\begin{array}{l}\text { CDCP I, II és III hasfali } \\
\text { környezet }\end{array}$ & 10 & Ismeretlen eredetû láz \\
\hline & & 11 & Pneumonia \\
\hline & & 12 & Bélelzáródás, ileus \\
\hline & & 13 & Alkoholizmus \\
\hline & & 14 & $\begin{array}{l}\text { Aktuális graviditás és } \\
\text { laktáció }\end{array}$ \\
\hline & & 15 & Aktuális kábítószer-élvezet \\
\hline
\end{tabular}

A hasfali rekonstrukció azonban számos esetben nem lehetséges, vagy a betegek rossz általános állapota, és/vagy a beteg akarata miatt. Ezek az esetek viszont megteremtették az alapját annak, hogy ezeket a betegeket pontosan kövessük és meghatározzuk a hasfal állapotának a változását, a hasfal hiányának növekedését, és regisztráljuk az eventeratióhoz vezető lényeges változásokat. A morfológiai adatok elemzése alapján vontuk le következtetéseinket, amely egy lehetséges és újdonságnak számító mútéti beavatkozás kialakításához is vezetett az eventerált hasfali sérvek és az extrém nagyságú hasfalhiányok zárásának tekintetében.

\section{Célkitüzés}

Olyan betegeknél végeztünk meghatározott időpontban CT-vizsgálatokat, akiknél nyitotthas-kezelések és intraabdominalis sorozatmútétek után a középvonal zárása a betegek beleegyezése hiányában vagy a gyenge általános állapotuk miatt nem volt lehetséges, így középvonali hasfalhiány és végső soron eventerált hasfali sérvek fejlődtek ki. A tanulmány elsődleges célja a középvonali hasfalhiány változásának a követése volt. A másodlagos cél a rectus abdominis izomzat, illetve az úgynevezett lateralis komponensek morfológiai változásainak a leírása a követéses vizsgálat során. Harmadlagos cél a hasfal morfológiai változásai alapján a CT-vizsgálatok jelentőségének a bemutatása a nagyméretú hasfalhiányok zárását illetően.

\section{Betegek és módszer}

A Debreceni Egyetem Klinikai Központjának Sebészeti Intézetében 2012. január l. és 2015. december 31. között összesen 12 betegnél (kilenc férfi, három nő) végeztünk konszekutív prospektív vizsgálatot. A vizsgálat előtt meghatároztuk a beválogatási és kizárási kritériumokat, a beválogatás végét, a CT követéses vizsgálatok idejét, valamint a tanulmány lezárásának idejét. Az adatokat folyamatosan gyújtöttük és a tanulmány végén statisztikailag elemeztük. Következtetéseinket 12 beteg adatainak elemzéséből vontuk le. A beválogatási időszakban összesen 19 betegnél történt nyitotthas- vagy intraabdominalis sorozatmútét, de csak 12 beteg felelt meg a beválogatásnak, és a követésesidőszakban is végig együttmúködtek. A tanulmány megfelelt a DE KK Etikai Bizottságának elvárásainak. Az Etikai Bizottság a tanulmányt $\mathrm{DE}$ RKEB/IKEB: 4599 számú engedéllyel támogatta. A tanulmány megfelelt az 1975-ös Helsinki Etikai Deklarációnak. A beválogatási és kizárási kritériumokat az 1 . táblázatban tüntettük fel. Nem volt kizáró ok a krónikus obstruktív tüdőbetegség (COPD) sem, amennyiben az ASA-score ötnél kisebb volt. Nem volt kizáró ok az aktív dohányzás és a nem rendszeres, mértékletes alkoholfogyasztás sem. A kezelt, egyensúlyban tartott diabetes mellitus nem volt kizáró ok. Az eventerált hasfali sérvekhez vezetô primer ok hat esetben nekrotizáló pancreatitis, öt esetben különböző okok miatt kialakult diffúz 
| A beválogatott 12 beteg lényeges klinikai adatai

\begin{tabular}{ll}
\hline Átlagéletkor (év) & $42,5 \pm 12,57$ \\
A primer mütét előtti átlagos testsúly $(\mathrm{kg})$ & $90,58 \pm 8,23$ \\
A primer mútétsorozat utáni átlagos testsúly, $\mathrm{T}_{0}(\mathrm{~kg})$ & $73,08 \pm 7,54$ \\
Átlagos testsúly a tanulmány végén, $\mathrm{T}_{12}(\mathrm{~kg})$ & $82,12 \pm 10,45$ \\
Átlagos testsúlyváltozás a tanulmány alatt $(\mathrm{kg})$ & $9,04 \pm 2,35$ \\
Átlagos BMI a sorozatmútétek előtt $\left(\mathrm{kg} / \mathrm{m}^{2}\right)$ & $29,31 \pm 2,22$ \\
Átlagos BMI a T időpontban $\left(\mathrm{kg} / \mathrm{m}^{2}\right)$ & $21,11 \pm 1,29$ \\
Átlagos BMI a tanulmány végén & $25,62 \pm 2,22$ \\
A hasfalhiány legnagyobb átlagos szélessége a & $19,7 \pm 8,22$ \\
tanulmány végén $(\mathrm{cm})$ & \\
A hasfalhiány átlagos hosszúsága $(\mathrm{cm})$ & $29 \pm 2,46$ \\
Átlagos hasfalhiány területe $\left(\mathrm{cm}^{2}\right)$ & $450,1 \pm 54,30$ \\
\hline
\end{tabular}

Az átlagéletkor feltúnően alacsony. A legkisebb hasfalhiány $395 \mathrm{~cm}^{2}$, a legnagyobb $576 \mathrm{~cm}^{2}$ volt.

peritonitis és egy esetben infrarenalis aortaaneurysmaruptura és annak következménye volt. Hat betegnek volt 1-es típusú és egy betegnek 2-es típusú kezelt cukorbetegsége (type I/II DM). A nekrotizáló pancreatitisek után öt betegnél alakult ki az inzulindependens DM, három betegnek volt több mint öt éve kezelt DM-je. Kezelt COPD-je három betegnek volt. Egy betegnek volt egyidejúleg kezelt ismert COPD-je és 2-es típusú cukorbetegsége. A sorozatmútétek utáni 1., 3., 6., 12., 18. és 24. hónapban $\left(\mathrm{T}_{0}-\mathrm{T}_{24}\right)$ CT-vizsgálatot végeztünk. A CT-vizsgálatokat 150-400 mA csőfeszültség (átlag: 350 $\mathrm{mA}$ ), 80-140 KV (átlag $120 \mathrm{KV}$ ) mellett, 2,5 mm-es szeletvastagsággal, zoom 1,2-1,7 paraméterekkel végeztük. Volumetrikus leképzés, 3D térfogatmérés nem történt ebben a tanulmányban. Röntgencsőáram- és feszültségmodulációt, optimalizációt és a pitch faktort (átlagosan $35 \mathrm{~mm} / \mathrm{s}$ asztalsebesség mellett $700 \mathrm{~mm}$-es vizsgálati hossz/20 s) a CT-készülék (Philips ${ }^{\mathrm{TM}}$ Lightspeed) automatikusan állította a rétegvastagság és a szöveti sürüség alapján $[6,7]$. A Th $\mathrm{XI}_{\mathrm{XI}}, \mathrm{L}_{\mathrm{II}}$ és $\mathrm{L}_{\mathrm{IV}}$ csigolyák felső széle magasságában meghatároztuk a középvonali hasfalhiány szélességét a rectushüvely medialis széle között mérve. Megmértük ugyanazon magasságban a rectushüvely szélességét és vastagságát mindkét oldalon, és a hasfalhiány legnagyobb hosszúságát. Minden esetben a legnagyobb szélességből (a) és hosszúságból (b) határoztuk meg a hasfalhiányok területét, az a/2 $\times \mathrm{b} / 2 \times \pi$ alapján. Az oldalsó hasfali komponensek tekintetében az obliquus internus és a transversus abdominis izmokat mértük meg egyenes vonalban a rectushüvely lateralis szélétől a középső hónaljvonal szintjéig. A vizsgálatban nem történt invazív vagy mútéti beavatkozás.

A statisztikai adatelemzéshez a Statistica for Windows (Version 13.0) programot használtuk. Minden mért folyamatosan változó értéket Kolmogorov-Szmirnovteszttel vizsgáltuk. Normális eloszlású adatok esetében az egymástól függő változók statisztikai különbségeit párosított Student-féle t-próbával vizsgáltuk, egyéb esetekben (egymástól független normális eloszlású változók esetében) a nem párosított Student-féle t-próbát alkalmaztuk. A többszörösen ismételt mérések értékelésének érdekében ismételt ANOVA-tesztet végeztünk. Az ANOVA-elemzést megelőzően az értékeket a normalitás (Kolmogorov-Szmirnov) és hogenitás (BrownForsythe) megállapítása céljából külön elemeztük. Az ANOVA-adatok post-hoc elemzésének elvégzéséhez Tukey-eljárást és elemzést végeztünk. Két normális eloszlású adathalmaz közötti bármely korreláció megállapításához Pearson-féle korrelációelemzést használtunk. A p-értéket kisebb, mint 0,05 alatt tekintettük statisztikailag szignifikánsnak.

3. táblázat |A CT morfológiai méréseinek átlagértékei különböző magasságokban

\begin{tabular}{|c|c|c|c|c|c|c|}
\hline & $\mathrm{T}_{0}$ & $\mathrm{~T}_{3}$ & $\mathrm{~T}_{6}$ & $\mathrm{~T}_{12}$ & $\mathrm{~T}_{18}$ & $\mathrm{~T}_{24}$ \\
\hline Átlagos középvonali hiány (cm) & 3,94 & 5,57 & 9,2 & 14,1 & 16,3 & 19,7 \\
\hline Rectushüvely-vastagság (cm) & 1,38 & 1,28 & 1,24 & 1,2 & 1,09 & 0,98 \\
\hline Jobb rectushüvely-szélesség $\mathrm{Th}_{\mathrm{XI}}(\mathrm{cm})$ & 7,36 & 7,27 & 7,08 & 6,89 & 6,7 & 6,49 \\
\hline Bal rectushüvely-szélesség $\mathrm{Th}_{\mathrm{XI}}(\mathrm{cm})$ & 7,46 & 7,34 & 7,25 & 6,99 & 6,55 & 6,23 \\
\hline Jobb rectushüvely-szélesség $\mathrm{L}_{\mathrm{II}}(\mathrm{cm})$ & 7,72 & 7,7 & 7,36 & 7,12 & 7,01 & 6,93 \\
\hline Bal rectushüvely-szélesség $\mathrm{L}_{\mathrm{II}}(\mathrm{cm})$ & 7,8 & 7,85 & 7,43 & 7,2 & 7 & 6,85 \\
\hline Jobb rectushüvely-szélesség $\mathrm{L}_{\mathrm{IV}}(\mathrm{cm})$ & 5,16 & 5,02 & 4,89 & 4,83 & 4,69 & 4,57 \\
\hline Bal rectushüvely-szélesség $\mathrm{L}_{\mathrm{IV}}(\mathrm{cm})$ & 5,27 & 5,13 & 4,87 & 4,83 & 4,68 & 4,63 \\
\hline Jobb és bal oldalsó komponens $\mathrm{Th}_{\mathrm{XI}}(\mathrm{cm})$ & 10,32 & 10,2 & 9,87 & 9,78 & 8,21 & 8,2 \\
\hline Jobb és bal oldalsó komponens $\mathrm{L}_{\mathrm{II}}(\mathrm{cm})$ & 10,4 & 10,37 & 9,91 & 9,78 & 8,34 & 8,38 \\
\hline Jobb és bal oldalsó komponens $\mathrm{L}_{\mathrm{IV}}(\mathrm{cm})$ & 10,23 & 10,1 & 9,85 & 9,24 & 8,11 & 8,14 \\
\hline
\end{tabular}

A középvonali hasfali defektus szélessége ötszörösére növekedett a tanulmány végére: Klinikailag teljes eventeratio alakult ki minden esetben. A rectusizomzat méreteinek változását az izomzat inaktivitásával lehet magyarázni. A rectusizom a három mért magasságban nem egyforma széles, ez az izom normális anatómiája. A lateralis hasfali komponensek fokozatosan rövidültek meg. Az értékek a kétoldali mérések összegét mutatják. Összesen mintegy 4 cm-es megrövidülést lehetett mérni a követés alatt. 


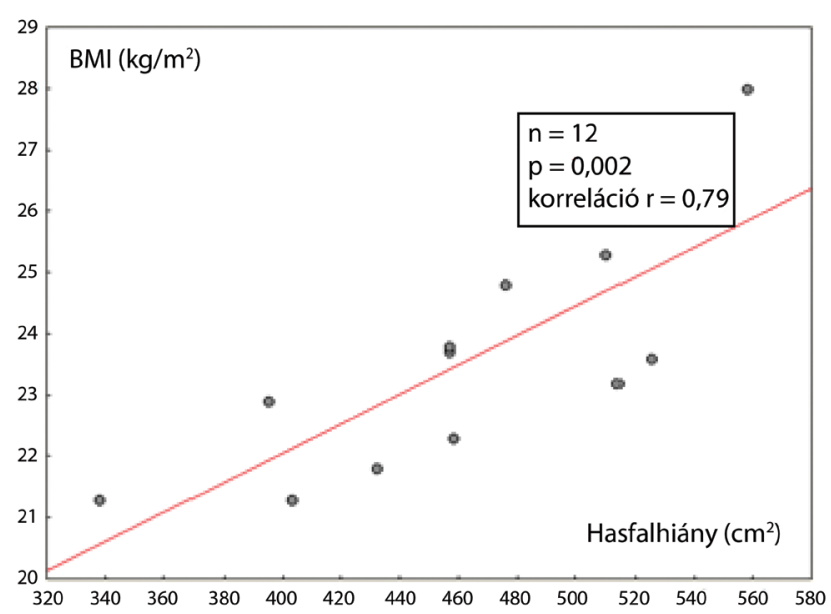

1. ábra

A BMI és a kialakult hasfalhiány közötti szoros és szignifikáns korreláció. Minél nagyobb volt a $\mathrm{T}_{-1}$ és $\mathrm{T}_{0} \mathrm{BMI}$, annál nagyobb hasfalhiány alakult ki $(\mathrm{p}=0,002$, korreláció $=0,79)$

\section{Eredmények}

Mind a 12 beteget végig tudtuk követni, mútéti beavatkozásra nem volt szükség. Egy beteg nem tudott megjelenni a $\mathrm{T}_{3}$ és $\mathrm{T}_{6}$, és egy beteg a $\mathrm{T}_{3}, \mathrm{~T}_{6}$ és a $\mathrm{T}_{18}$ CT-vizsgálatokon, ami szignifikáns eltérést az eredményekben nem okozott. A betegekre vonatkozó klinikai adatok a 2. táblázatban láthatók. A betegek felénél akut nekrotizáló pancreatitis miatt történt a primer mútétsorozat, az átlagéletkoruk $35,3 \pm 5,33$ év volt, amely miatt a 12 beteg átlagéletkora is nagyon alacsony $(42,5 \pm 12,6$ év) volt. A hosszadalmas primer kezelés során a betegek jelentős testsúlyt vesztettek. A mútétsorozat előtt $\left(\mathrm{T}_{-1}\right)$ a betegek átlagos $29 \mathrm{~kg} / \mathrm{m}^{2}$ BMI-értéke a tanulmányba történő beválogatás idejére $\left(\mathrm{T}_{0}\right) 21 \mathrm{~kg} / \mathrm{m}^{2}$-re csökkent, majd a követéses időszak végére $25 \mathrm{~kg} / \mathrm{m}^{2}$-re emelkedett. A $\mathrm{T}_{0}$ és $\mathrm{T}_{24}$ idôpontokban számított BMI szoros és szignifikáns korrelációt mutatott a kialakult hasfalhiány $\mathrm{cm}^{2}$-ben számított területével $(\mathrm{p}=0,002$, korreláció $\mathrm{r}=0,79)$ (1. ábra). A hasfalhiány gyakorlatilag a teljes középvonalat érintette, az eredeti teljes laparotomia hosszának megfelelően. A $\mathrm{T}_{24}$ időpontban a hasfalhiány hosszúsága és legnagyobb szélessége alapján a hasfalhiányok átlagos nagysága $450(395-576) \mathrm{cm}^{2}$ volt.

$\mathrm{A} \mathrm{T}_{0}-\mathrm{T}_{24}$ idópontokban a $\mathrm{Th}_{\mathrm{XI}}, \mathrm{L}_{\mathrm{II}}$ és $\mathrm{L}_{\mathrm{IV}}$ csigolya magasságában a 3. táblázatban látható átlagértékeket mértük a középvonali hasfalhiány, a rectusvastagság és a rectusizmok szélességének tekintetében. A középvonali hasfalhiány folyamatos és majdnem lineáris növekedést mutatott a két időpont között (2. A) ábra), a növekedés szignifikáns $(\mathrm{p}=0,0002)$. A rectushüvely vastagsága folyamatos csökkenést mutatott, az izom elvékonyodott (2. B) ábra). A rectusizomzat változásaival egy időben a középvonali hasfalhiány szélessége a harmadik hónapban az $\mathrm{L}_{\mathrm{II}}$ szintjében mért átlagos $5 \mathrm{~cm}$-rő́l az egyéves vizsgálat során mért $15 \mathrm{~cm}$-re növekedett. Az elsố évben a változás mértéke háromszoros volt. A tanulmány végére a harmadik hónapban mért értékhez képest négyszeresére
A

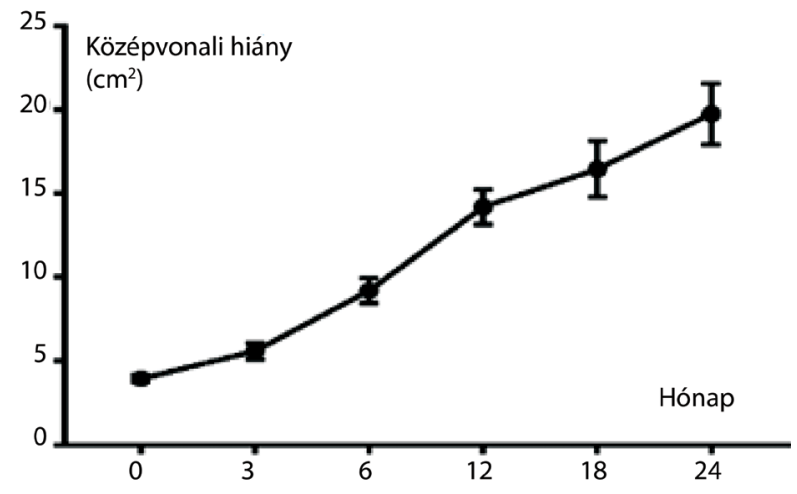

B 2

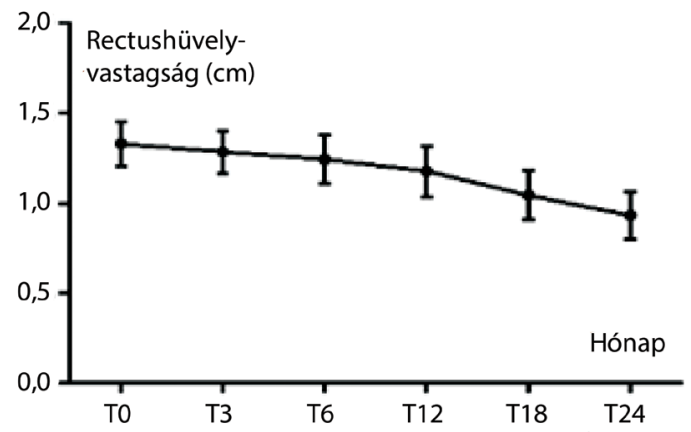

C

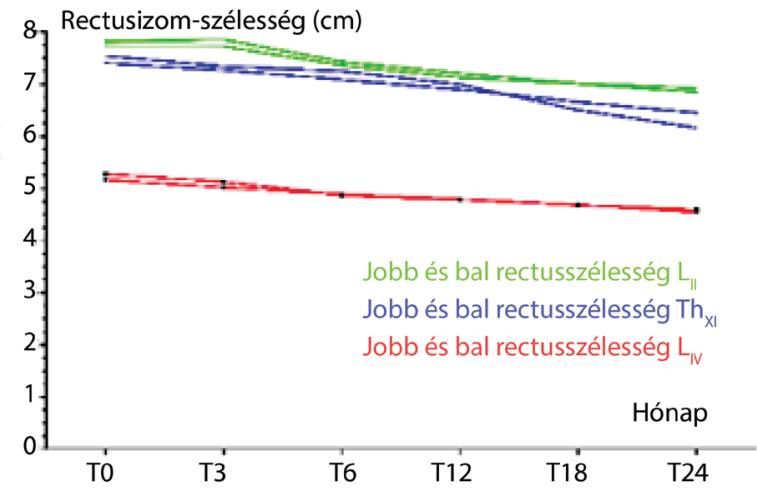

2. ábra

Az átlagos középvonali hasfalhiány növekedése (A). Az átlagos rectusizomzat vastagságának változása a $\mathrm{T}_{0}-\mathrm{T}_{24}$ között az $\mathrm{L}_{\mathrm{II}}$ magasságban mérve $(\mathrm{B})$. A kétoldali rectusizmok szélességének változása mindhárom vizsgált $\mathrm{CT}$-síkban $(\mathrm{C})$. Mindkét oldalon, minden síkban szignifikáns csökkenést mértünk

növekedett a hasfalhiány átlagos szélessége. A kétoldali rectusizom nem volt egyforma széles az egyes magasságokban, viszont minden magasságban mérve az izom szélessége folyamatos csökkenést mutatott (2. C) ábra). A csökkenés mértéke az izom szélessége $(\mathrm{p}=0,45)$ és vastagsága $(\mathrm{p}=0,213)$ tekintetében is szignifikáns volt. A 3. és 4. ábrán látható a kezdeti $\left(\mathrm{T}_{0}\right)$ és a végső $\left(\mathrm{T}_{24}\right)$ állapotok jellegzetes CT-képe. A három különböző magasságban mért rectusizom átlagos szélessége az $\mathrm{L}_{\mathrm{II}^{-}}{ }^{-}$ szintben volt a legnagyobb $(7,76 \mathrm{~cm})$, ezt követte a $\mathrm{Th}_{\mathrm{XI}}$ $(7,41 \mathrm{~cm})$, majd az $\mathrm{L}_{\mathrm{IV}}(5,21 \mathrm{~cm})$ magasságban mért érték. 


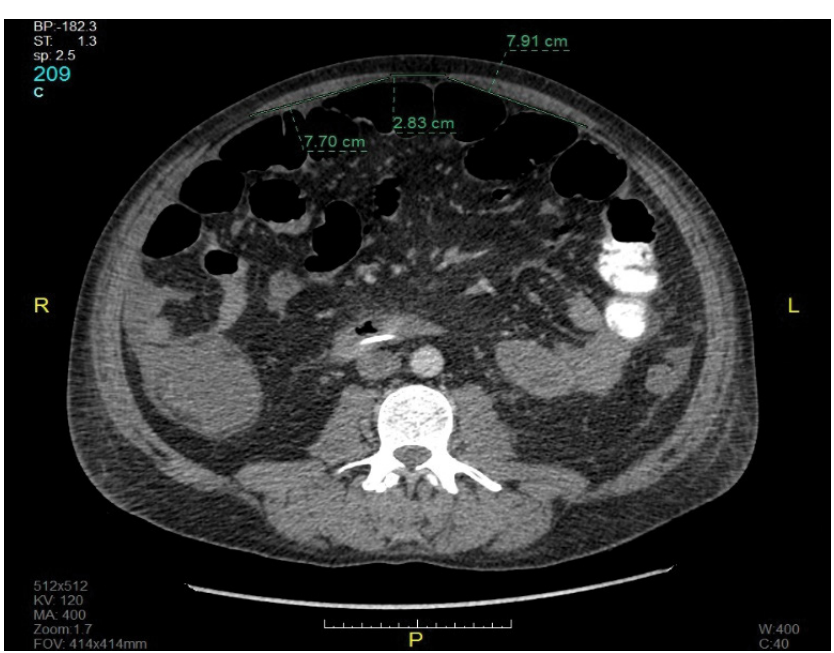

\begin{tabular}{l|l} 
3. ábra & Típusos CT-kép a $\mathrm{T}_{0}$ időpontban. A hasfalhiány szélessége még
\end{tabular} $3 \mathrm{~cm}$-nél kisebb, a rectusizmok és a lateralis komponensek szabályosak, nem lateralizáltak

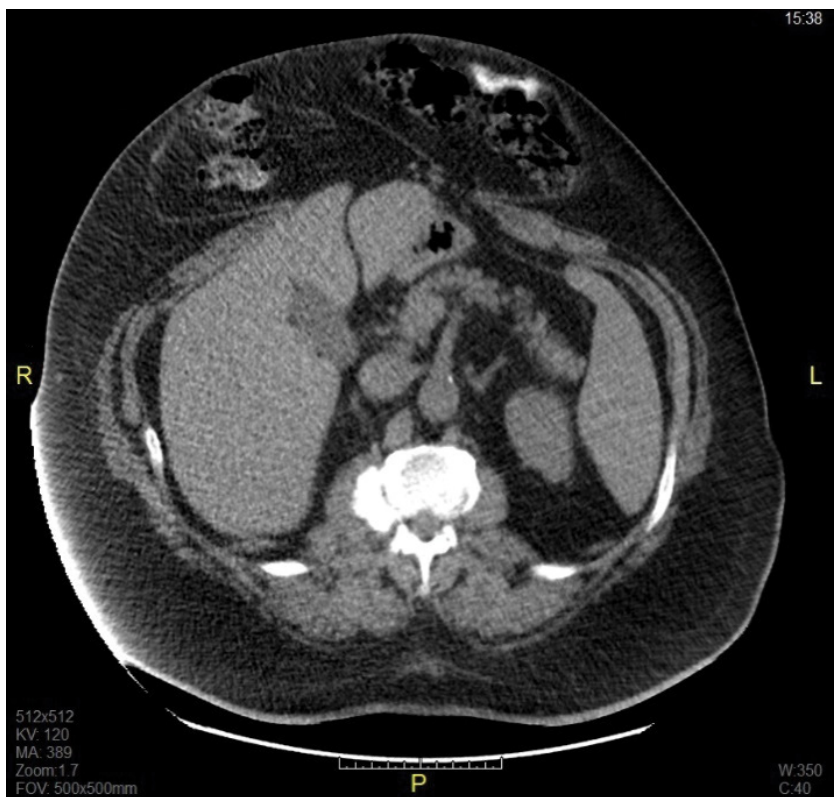

4. ábra

$\mathrm{T}_{24}$ időpontban kifejlődött eventerált óriás hasfali sérv. A hasfa hiánya $576 \mathrm{~cm}^{2}$ volt. A rectusizomzat mindkét oldalon megtartott. Az obliquus és transversus izmok oldalirányú elmozdulása és rövidülése jól látható. Ebben az állapotban az ACS-, PCS- és TAR-technikák nem alkalmasak az extrém nagy hiány biztos és tartós zárására

A belső ferde és harántizmok a rectushüvely lateralis széle és a középső hónaljvonalig mért együttes távolsága a $\mathrm{T}_{0}$ és $\mathrm{T}_{24}$ között folyamatos csökkenést mutatott (3. táblázat). A csökkenés mértéke a $\mathrm{Th}_{\mathrm{XI}}, \mathrm{az} \mathrm{L}_{\mathrm{II}}$ és az $\mathrm{L}_{\mathrm{IV}}$ magasságban sorrendben $2,12 \pm 0,56,2,02 \pm 0,64$ és $2,09 \pm 0,49$ cm volt.

\section{Megbeszélés}

A hasfali izomzat integritása, egységes szerkezete congenitalis, tompa vagy éles sérülések, illetve sebészi beavatkozások következtében változhat vagy szünhet meg [8].
Tanulmányunkban a kezelését illetően a legnagyobb kihívást jelentő, sebészeti beavatkozások után kialakuló eventerált, óriás hasfali sérvek kifejlődését, valamint a hasfal szerkezetének változásait vizsgáltuk meg. Az eventerált hasfali sérvek meghatározó tulajdonságait (a sérv térfogata, a sérv tartalma, a hasfalhiány pontos lokalizációja, a hasfalhiány nagysága, a hasfali defektusok száma) CT- vagy MR-vizsgálattal pontosan meg lehet határozni [9-11]. Tanulmányunk legfontosabb kérdése a kezdeti $\left(\mathrm{T}_{0}\right)$ és a végső $\left(\mathrm{T}_{24}\right)$ időpont közötti történések meghatározása volt, ami a középvonali hasfalhiány és a hasfali izomelemek időbeli változásait foglalta magába. A hasüregi sorozatmútétek és nyitotthas-kezelések után a középvonali integritás rendszerint hiányzik, így eddig nem alkalmazott, jól használható modellt nyújtott a fenti változások pontos megfigyeléséhez.

A középvonali hasfalhiány változása közel lineáris oldalirányú növekedést mutatott, ami a követéses időszak végéig megmaradt. Ugyanakkor mindkét oldalon a rectusizomzat szélességének és vastagságának egyaránt egyenletes, fokozatos, statisztikailag szignifikáns csökkenését igazoltuk (5. ábra). Az ábrából levonható leglényegesebb megfigyelés az, hogy a középvonali hasfalhiány átlagos legnagyobb szélessége a követés során a 12. hónaptól kezdődően azonos a kétoldali rectusizom együttes szélességével. A $\mathrm{T}_{18}$-ig a középvonali hiány átlagos szélessége és a rectusizmok szélessége egymással öszszevethető, jelentősen nem tér el egymástól. A $\mathrm{T}_{12}$ előtt a hasfalhiány még kisebb, mint a rectusizmok együttes szélessége, a $\mathrm{T}_{18}$ után viszont a rectusizmok már nem elég szélesek, hogy képesek legyenek lefedni az időközben az eredeti ötszörösére növekedett középvonali hiányt.

A rectushüvelytől lateralisan az oldalsó hasfali komponensek is megrövidültek. A linea semicircularis átlagosan $2 \mathrm{~cm}$-rel került lateralisabb helyzetbe az eredeti helyzeté-

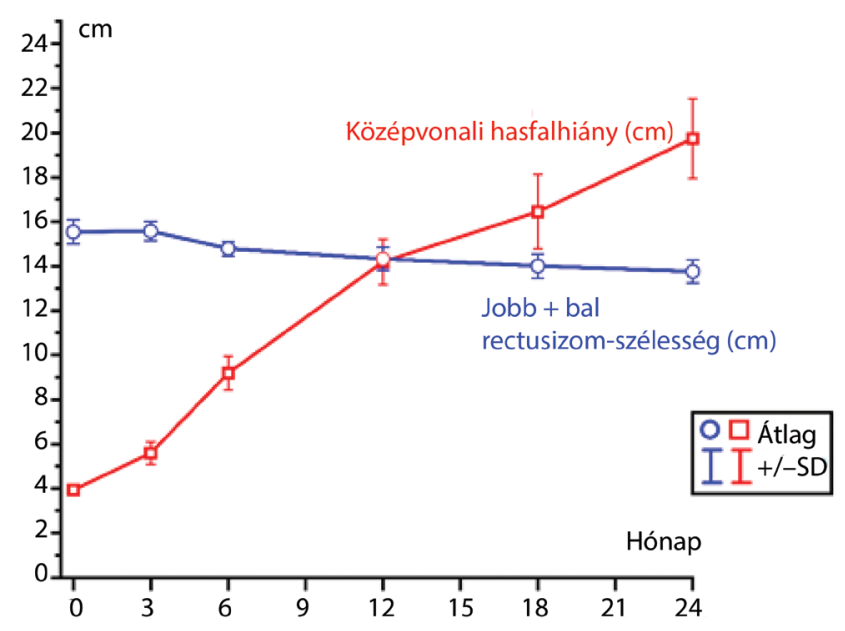

5. ábra $\quad$ A középvonali hasfalhiány és a rectusizmok változása a követés alatt. $\mathrm{A}_{12}-\mathrm{T}_{18}$ időpont között „felel meg” egymásnak a rectusizmok együttes szélessége és hasfalhiány. Ebben az intervallumban a megfelelő technikával mobilizált rectusizmokkal a nagyméretű hasfalhiány feszülés nélkül és biztonságosan fedhető biológiai vagy szintetikus graft implantációja nélkül 
hez képest, ami azt jelentette, hogy a transversus és obliquus internus izmok lateralizációja mintegy $4 \mathrm{~cm}$-rel „járult hozzá” a középvonal hiányához. A hasüreg felőli nyomás és a hasfali izmok oldalirányú trakciós hatása egy viszonylag egyenletesen növekedő középvonali hiányt hozott létre. A kialakult hasfalhiány annál nagyobb lett a követés végére, minél magasabb volt a beteg BMI-értéke. A korreláció érvényes volt a $\mathrm{T}_{-1}$ és a $\mathrm{T}_{0}$ időpontokban mért BMI-értékekre egyaránt.

A CT-vizsgálatok gyakorlati jelentősége az óriás hasfali sérvek rekonstrukciójában az, hogy pontos információt ad a hasfali izomelemek pontos méreteiről, és ezeknek az elemeknek a felszabadítása, szeparálása pontosan mekkora távolságot jelent a sérvek zárása, a hasfalhiány fedése során. A mütétek előtt elvégzett CT-vizsgálattal arról szükséges megbizonyosodni, hogy a hasfal saját elemeinek meghatározott mobilizálása képes lesz-e a beavatkozás során feszülés nélkül fedni a hasfal hiányát. Az eventerált hasfali sérvek rekonstrukciója során a legtöbb problémát az jelenti, hogy a három leggyakrabban alkalmazott technika (ACS, PCS, TAR) nem biztosít elegendő hasfali izomfelszabadulást és medializációt, amely önmagában (xenograft, ADM, illetve szintetikus graft különböző alkalmazása nélkül) elegendő lenne a hasfalhiány biztonságos, tartós és feszülés nélküli zárásához [12-14].

Az eventerált, óriás hasfali sérvek CT-elemzése során azt figyeltük meg, hogy a hasfal hiánya (átlagosan $\mathrm{T}_{12}$ nél $14 \mathrm{~cm}, \mathrm{~T}_{24}$-nél $19 \mathrm{~cm}$ ) a jelenleg alkalmazott komponensszeparációs technikákkal (ACS, PCS, TAR) nem fedhető le, nem vagyunk képesek olyan mértékú hasfali komponensfelszabadulást elérni, hogy lényeges feszülés nélkül fedni tudjuk a hasfal hiányát. Az egyes izomkomponensek közül egyedül a kétoldali rectus abdominis izom együttes szélessége összevethető a középvonali hasfalhiánnyal, azonban ez a sérvfejlődési folyamat csak egy bizonyos szakaszára érvényes. Ez az időintervallum tanulmányunkban a $\mathrm{T}_{0}$ időponttól számított $\mathrm{T}_{12}$ és $\mathrm{T}_{18}$ között, pontosabban a 12. és 15 . hónap között optimális. Ebben az intervallumban a kétoldali rectusizom szélessége együttesen és a hasfali defektus szélessége közel egyforma. Ez előtt az időpont előtt a rectusizmok szélessége még meghaladja, ez után az intervallum után pedig már nem képesek lefedni a hiányt. Azt a következtetést vontuk le, hogy az optimális időintervallumban a rectusizmok felszabadítása és a középvonal felé történő „átfordítása" feszülés nélkül képes a hasfali defektus teljes fedésére. Tapasztalataink alapján az eventerált hasfali sérvek rekonstrukciója előtt a CT-vizsgálatok elvégzése és pontos elemzése lehetővé teszi a mútéti technika megtervezését, és előre fel lehet készülni arra, hogy az egyes lehetőségek közül melyik az, amelyik legkevésbé megterhelő a beteg számára, továbbá feszülés nélkül képes a hasfal zárására és idegen anyag implantációját lehetőleg elkerüli.

\section{Következtetések}

A nyitott hasi mütétek és a retroperitonealis sorozatmütétek után kifejlődő középvonali hasfali sérvek eventeratióhoz vezetnek. Tanulmányunkban azt tudtuk igazolni, hogy az eventeratio kialakulása időben egy karakterisztikus dinamikát követ. Megváltozik a hasfali izomelemek anatómiája és mérete. Irreverzibilis változások következnek be az izomelemek egymáshoz viszonyított helyzetében. A hasfali musculoaponeuroticus elemek változásait CT-vizsgálattal pontosan lehet követni. A CT-vizsgálat, véleményünk szerint, az eventerált hasfali sérvek megoldása előtt mindenképpen ajánlott, amely alapján a komponensszeparációs technikák közül kiválasztható a legoptimálisabb megoldás. Amennyiben a sérvfejlődést követni tudjuk időben, akkor a középvonali hasfalhiány zárásának optimális időpontja a primer mútétsorozat után 12-15 hónap között határozható meg. A lehetséges technikák közé sorolunk egy először általunk alkalmazott beavatkozást is, amelynek az alapötletét és a mütéttechnikai részleteinek a kidolgozását a jelenleg bemutatott tanulmány során elvégzett CT-vizsgálatok részletes elemzése nyújtotta.

Anyagi támogatás: A közlemény megírása anyagi támogatásban nem részesült.

Szerzői munkamegosztás: M. G.: A közlemény alapötlete, megírása, betegkövetés, adatgyüjtés. L. R.: Statisztikai adatelemzés. D. L.: A közlemény kritikai átnézése, korrekciós javaslatok. A cikk végleges változatát valamennyi szerző elolvasta és jóváhagyta.

Érdekeltségek: A szerzőknek nincsenek érdekeltségeik.

\section{Irodalom}

[1] Petro, C. C., Como, J. J., Yee, S., et al.: Posterior component separation and transversus abdominis muscle release for complex incisional hernia repair in patients with a history of an open abdomen. J. Trauma Acute Care Surg., 2015, 78(2), 422-429.

[2] Ross, S. W., Oommen, B., Heniford, B. T., et al.: Component separation in complex ventral hernia repair: surgical technique and postoperative outcomes. Surg. Technical Int., 2014, 24, 167177.

[3] Winder J. S., Behar, B. J., Juza, R. M., et al.: Transversus abdominis release for abdominal wall reconstruction: early experience with a novel technique. J. Am. Coll. Surg., 2016, 223(2), 271-278.

[4] Novitsky, Y. W., Elliot, H. L., Orenstein, S. B., et al.: Transversus abdominis muscle release: a novel approach to posterior component separation during complex abdominal wall reconstruction. Am. J. Surg., 2012, 204(5), 709-716.

[5] Roth, F. S., Troy, J. S., Schusterman, M. A.: Tranverse dual-perforator fascia-sparing free TRAM flap: technique description. Plast. Reconstr. Surg., 2012, 128(5), 1039-1042. 
[6] Horton, K. M., Sheth, S., Corl, F., et al.: Multidetector row CT principles and clinical applications. Crit. Rev. Comput. Tomogr., 2002, 43(2), 143-181

[7] Silverman, P. M., Kalender, W. A., Hazle, J. D.: Common terminology for single and multislice helical CT. AJR Am. J. Roentgenol., 2001, 176(5), 1135-1136.

[8] Stensby, J. D., Baker, J. C., Fox, M. G.: Athletic injuries of the lateral abdominal wall: review of anatomy and $M R$ imaging appearance. Skeletal Radiol., 2016, 45(2), 155-162.

[9] Ianora, A. A., Midiri, M., Vinci, R., et al.: Abdominal wall hernias: imaging with spiral CT. Eur. Radiol., 2000, 10(6), 914 919.

[10] Toms, A. P., Cash, C. C., Feranado, B., et al.: Abdominal wall hernias: a cross-sectional pictorial review. Semin. Ultrasound CT MR, 2002, 23(2), 143-155.

[11] Aquierre, D. A., Santosa, A. C., Casola, G., et al.: Abdominal wall hernias: imaging features, complications, and diagnostic pitfalls of multi-detector row CT. Radiographics, 2005, 25(6), 15011520 .

[12] Lisiecki, J., Kozlow, J. H., Agarwal, S., et al.: Abdominal wall dynamics after component separation hernia repair. J. Surg. Res., 2015, 193(1), 497-503

[13] Lappäniemi, A., Tukiainen, E.: Planned hernia repair and late abdominal wall reconstruction. World J. Surg., 2012, 36(3), 511-515.

[14] Pauli, E. M., Wang, J., Petro, C. C., et al.: Posterior component separation with transversus abdominis release succesfully addresses recurrent ventral hernias following anterior component separation. Hernia, 2015, 19(2), 285-291.

(Martis Gábor dr., Debrecen, Móricz Zsigmond krt. 22., 4032 e-mail: gabor6911@gmail.com)

\title{
A Magyar Endokrinológiai és Anyagcsere Társaság (MEAT)
}

\author{
pályázatot hirdet a 2017. évi MEAT Ifjúsági Díjra
}

Pályázati feltételek:

(1) A pályázó életkora a pályázat beadásakor nem haladhatja meg a 35 évet.

(2) Pályázni lehet a tárgyévben vagy az azt megelőző évben megjelent vagy közlésre elfogadott dolgozattal.

(3) A pályázatra benyújtott dolgozat témájának az endokrinológia vagy a neuroendokrinológia tárgykörébe kell tartoznia.

(4) Hazai laboratóriumban készült és önállóan végzett kutatómunka előnyben részesül.

(5) Többszerzős munka esetén a pályázó a dolgozat első szerzője kell legyen.

(6) MEAT tagság

Az Ifjúsági Díjat évente egy pályázó nyerheti el, a díj díszoklevélböl és egy összegben kifizetett ösztöndíjból áll (150 000 forint). A díj odaítélésére a MEAT elnöke által felkért bírálóbizottság tesz javaslatot, a végleges döntést a MEAT vezetősége hozza meg.

A pályázat beküldési határideje: 2017. március 31 .

A nyertes pályázó dolgozatát a MEAT 2018. évi kongresszusán ismerteti.

A pályázatot a MEAT fötitkárához (Prof. Dr. Tóth Miklós, Semmelweis Egyetem, II. Belgyógyászati Klinika, toth.miklos@med.semmelweis-univ.hu) kell benyújtani (pályázat + megjelent/elfogadott dolgozat elektronikus változata + szakmai önéletrajz). A pályázónak nyilatkoznia kell, hogy a társszerzőket előzetesen értesítette a dolgozat pályázatra történő benyújtásáról. 